\title{
The Implementation of HOTS in Teaching English Process at Tenth Grade of MTI Pasia
}

\author{
Sesmiyanti ${ }^{1}$ \\ ${ }^{1}$ Corresponding author, IAIN Bukittinggi, Sumatra Barat, Indonesia; \\ miases75@gmail.com
}

Received: Desember 30, $2020 \quad$ Accepted: January 21, 2021 $\quad$ Published: January 21, 2021

\begin{abstract}
This research was conducted because HOTS is a significant factor in achieving the learning process in accordance with the 2013 curriculum, HOTS is a solution that students become active and participatory in the learning process, teachers not only explain learning in front of the class, but students must be more active to describe the problems that were found during learning, therefore, the researcher wanted to investigate how the HOTS process was implemented in teaching English at X grade of MTI Pasia in the 2019/2020 school year. The purpose of this research is to know how the English teacher at X grade of MTI Pasia apply HOTS in teaching English process, especially in developing productive and receptive skills according to the level of critical thinking. This research was a qualitative descriptive study using documentation (document analysis) and observation sheets to collect the data. The subjects in this study was $\mathrm{X}$ grade English teachers at MTI Pasia in the 2019/2020 academic year. The results of this study obtained from the document analysis and observation sheets found that, the English teacher at X grade of MTI Pasia did not apply HOTS in teaching English and learning process. The English teacher only applied HOTS to the learning design, it was not applied to the process in learning, this happened not because of online learning due to COVID 19 pandemic, but it was happened because the teacher did not encourage learning to be effective during the pandemic, the teacher should still be able to improve the learning process using technological advances even though it was still far from perfection compared with face-to-face learning.
\end{abstract}

Keywords: Implementation; HOTS; Teaching strategy

To cite this article: Sesmiyanti. (2021). The Implementation of HOTS in Teaching English. SALEE: Study of Applied Linguistics and English Education, 2(01). https://doi.org/10.35961/salee.v2i01.215

DOI: $10.35961 /$ salee.v2i01.215 


\section{Introduction}

Education in the 21 st century is simply interpreted as transformed learning. It means that, skills that are need to be achieved by students is not only LOTS (Lower Order Thinking Skills), but there must also be an increase to HOTS (Higher Order Thinking Skills). HOTS is a process of thinking in a higher cognitive level that is developed from a variety of cognitive concepts and methods and taxonomies of learning, teaching, and assessment. The main purpose of high order thinking skills is how to improve the ability to think critically in receiving various types of information. So, HOTS can be one way to encourage students to be able to solve their own problems by thinking critically.

Margana \& Widyantoro said that point out that the use of critical thinking (higher-order thinking skills) is recognized as a main capability to maximally enhance students' academic language. From that notion, the relationship between thinking and language learning particularly in writing, speaking, listening and reading skills are highly significant. Higherorder thinking skills includes some active skills which with those active skills the students can handle their productive task. It is believed that to improve students' productive and receptive skills also need to improve their higher-order thinking skills.

It can be concluded that integrating HOTS into learning is a must, it is intended that HOTS is not just about making questions for assessment. HOTS in learning means the ability to think critically, logically, reflectively and metacognitively. The 2013 curriculum demands that learning materials are designed to encourage students to be able to predict, design, and predict. The teacher-centered learning model is no longer relevant. Students should be the center of learning (student-centered learning).

\section{Method}

The design of this research is qualitative research. Sugiyono states that qualitative research is the research method that based on post-positivism philosophy which is used to research natural condition where researcher as main instrument. the researcher will apply descriptive qualitative because it can help the researcher to get information from informant based on the research question, and this purpose to know how the implementation of HOTS in teaching English, so the qualitative design is an appropriate research design to use in this research.

\subsection{Respondents}

This study was conducted at MTI Pasia. The respondent was the English teacher of tenth grade students of MTI Pasia determined by using Purposive sampling. As Margono stated, purposive sampling is used if the sample has some certain criteria that relate to the purpose of the study. There is the teacher in teaching English at tenth grades of MTI Pasia, the teacher said that, the teacher used HOTS criteria in teaching English process. Then, researcher choose one teacher as the key of informant of this research.

\subsection{Instruments}

The instruments used to collect the data were used observation and document analysis. For document analysis, the researcher analysed the lesson plan that made by the teacher based on HOTS criteria. 


\subsection{Procedures}

The researcher started the research by determining the respondent and collecting the data through observation and document analysis. The following steps were data analysing and concluding.

\subsection{Data Analysis}

After the data collected, the researcher analyses the data from documentation and observation to achieve the intended purposes. Miles and Huberman in Sugiyono, the procedures are: data reduction, data display, Conclusion drawing or verification, Trianggulation of the data.

\section{Finding and Discussion}

Based on the description of how teachers' understanding the lesson plans following HOTS criteria, the researcher found that the teacher understood of the lesson plans even though some parts could not find in the lesson plan, for example about how productive skills and receptive skills techniques were developed. The teacher did not describe the material to be used. Besides, the teacher made the lesson plans according to HOTS criteria.

Based on a description of how the teacher implements HOTS in the English learning process, the researcher found that teachers did not develop HOTS properly. According to Goodson and Rohani said that applying HOTS-based learning there must be activities that stimulate students to develop the ability to analyze, evaluate and create, this will be achieved if learning takes place in active learning where students are the centre. The teacher did not stimulate students to be able to solve their problems. there was not feedback process occurs between teachers and students, only teachers who active in learning, and it can be concluded that learning was still focused on the teacher.

Based on a description of how the teachers increase productive and receptive skills according to the HOTS criteria, the researcher found that there was not increase at all in students' productive and receptive skills, because the teacher did not develop these two skills. First, in the teacher's writing activity did not teach how to develop ideas properly. The teacher only provided practice to answer the questions that have been given. So it caused students to only analyze but not writing it, in speaking activities, the teacher also did not do speaking activities to students, this happened not because of limitations in the online learning process but the teacher did not do anything for this, students were only given dialogue without doing anything. Listening activities, the researcher did not find listening activities during 5 meetings, but reading activities did happen quite well. The teacher gave a reading text then the students were asked to analyze the reading text, then for the reading process the teacher gave the material and the students answered the questions, so productive skill activities and receptive skills are not taught well at all.

According to Rosli and Maarof emphasize that HOTS acts as a guide for the students to develop their ideas on what they want to write, with HOTS the students are also trained to improve their speaking ability by explaining their ideas and attempting to state what is on their mind to their friends. According to Setyarini and Ling find that the students who have 
critical thinking skills are willing to deliver their ideas freely in front of the class without worrying their friends' judgment or mistake. So, those advantages will be owned by the students when the students to integrate their higher-order thinking skills with English productive skills and receptive skills.

The implementation of HOTS in teaching productive skills and receptive skills can help students' understanding, but the facts were found that there was not process of improvement until the assessment occurs. Teachers only focused on the material. Here, researchers could emphasize that this happened not because of the online learning process, but the teacher did not provide or teach according to the 4 skills needed, there was not speaking process, there was not writing process that made students knew what the students wrote, there was not reading process even though the teacher has given readings to students, there was not listening process given by the teacher. So, at this stage, the process did not happen at all.

Thus, it can be concluded that the implementation of HOTS by the English teacher was not going well, because the teacher did not teach students directly, it happened because of the Covid 19 pandemic which made it difficult for students to be active in learning, it was not an excuse for the teachers to did not prepare strategies to support a conducive learning process during a pandemic. The teacher only provided material, then students were asked to understand the material, and then the teacher gave exercises to the student. The learning process only took place about 20 minutes, only through WAG and google classroom. So, it was very far from the process of ideal learning.

\section{Conclusion}

The researcher concluded that this research focused on the Implementation of HOTS in teaching English. The results obtained that the teacher did not use HOTS in the learning process, the teacher only understands the HOTS criteria only in the lesson plan, the teacher implemented HOTS well in the lesson plan, while in the learning process itself, the teacher did not apply the HOTS process properly. For the productive and receptive skills, there was not level of thinking were found during the learning process, it could be said that for the productive skills process, the teacher did not apply HOTS at all in learning, and for receptive skills teachers also did not apply HOTS well in the learning process. The learning process was still focused on students, there was not improvement has occurred, this happened because the skill was not taught at all. 


\section{References}

Anderson, L., kratwohl, m. R., Airasian, P.W., Cruikshank, K. A., Mayer, R.E., Pintrich, P.R. (2001). A axonomy for learning, Teaching, and Assessing: A revision of Blooms Taxonomy of Educational Objectives (complete edition). New York: Longman

Bamanger \& Gashan. (2014). "In-Service EFL Teachers "e Beliefs about Teaching Reading Strategies". Canadian Center of Science and Education.

Broughton Geffrey. (1980). Teaching English as a Foreign Language. New York: Routledge.

Carol griffiths. (1997). English language learning strategy. Toronto: Ontario Institute for studies in education.

Christopher Klopper and steve drew. (1987). Teaching for learning and learning for teaching. Clayton, Australia: Monash University.

Emi Rofiah, Nonoh Siti Aminah, and Elvin Yusliana Ekawati (2013) 'Penyusunan Instrumen Tes Kemampuan Berpikir Tingkat Tinggi Fisika Pada Siswa SMP', Jurnal Pendidikan Fisika

Flower, L. A. \& Hayes, J. R. (1981). A cognitive process theory of writing. College composition and communication

Gordon Eisenman and Beverly D Payne. (2016). 'Effects of the Higher Order Thinking Skills Program on At-Risk Young Adolescents' Self-Concept, Reading Achievement, and Thinking Skills Effects of the Higher Order Thinking Skills Program on At-Risk Young Adolescents' and Thinking Skills', Routledge Taylor and Francis Group

Husamah. (2016). Belajar dan pembelajaran. Universitas Muhamadiyah Malang.

King, FJ, Ludwika Goodson, and Faranak Rohani. (1997). Higher Order Thinking Skills; Definition, Teaching Strategies, Assessment. Tersedia pada: cala.fsu.edu.

Langer, Judith, A. (1991). Literacy and schooling: A sociocognitive perspective, In Hiebert Elfrieda, (Ed.), Literacy for a diverse society: Perspectives, practices and policies, New York: Teachers CollegePress.

Gay, L.R.(1990). Educational research. Singapore: Merill Publishing company

Margana, \& Widyantoro, A. (2017). January. Developing English textbooks oriented to higherorder thinking skills for students of Vocational High Schools in Yogyakarta. Journal of Language Teaching and Research.

Margono. (2007).Metode Penelitian pendidikan, Jakarta: Rhineka Chipta,

Moffett, J. \& Wagner, B. J. (1983). Student-centered language arts and reading, K-13: A handbook for teachers. (3rd. ed.). Boston, MA: Houghton-Mifflin Co.

Newman, F. M. (1990). "Higher Order Thinking in Teaching Social Studies: A Rationale For The Assessment of Classroom Thoughtfulness." Journal of Curricular Studies

Nichols, J. 2013. 4 Essential Rules of 21st Century Learning. London. 
Perkins, D. N. (1993). Teaching for understanding. American Educator, Fall

Riska Sriharyanti. (2017). Pengembangan Desain Pembelajaran Menggunakan Model Pembelajaran Discovery Learning Berbasis Higher Order Thinking Skill Pada Siswa Kelas V Tema 6 Subtema 2 Di SD Negeri 2 Labuhan Ratu (Skripsi Program Studi Pendidikan Guru Sekolah Dasar, Universitas Lampung, Lampung,)

Rosenblatt, L. M. (1978). The reader, the text and the poem. Carbondale, IL: Southern Illinois University

Sugionom (2010) Methodologi Penelitian Kualitatif and $R \& D$. Bandung: aksara medika beta

Susan M Brookhart, (2010). How to Assess Higher Order Thinking Skills in Your Classroom (ASCD: Alexandria, Virginia USA)

Tan Shin Yen and Siti Hajar Halili. 2015 'Effective Teaching Of Higher-Order Thinking (HOT)InEducation', Journal Of Distance Education And E-Learning Tenaga pendidikan kementrian pendidikan dan kebudayaan. 2018. Buku pegangan pembelajaran berorientasi pada keterampilan berpikir tingkat tinggi. Direktorat Jenderal Guru dan Tenaga Kependidikan. Jakarta.

Weay, A. L., Masood, M., \& Abdullah, S. H. (2016). Systematic review of revised Bloom Taxonomy, SOLO Taxonomy and Webb's Depth of Knowledge (DOK) in assessing students' historical understanding in learning history. Malaysian Journal of Higher Order Thinking Skills In Education

Yoki ariyana, MT. (2018). Buku pegangan pembelajaran HOTS. Direktorat jendral guru dan tenaga kependidikan kementrian pendidikan dan kebudayaan.

Zohar, A., Degani, A., \& Vaaknin, E. (2001). Teachers' Beliefs about Low-Achieving Students and Higher Order Thinking. Teaching and Teacher Education 